\title{
PENGEMBANGAN MULTIMEDIA INTERAKTIF PADA MATERI PESAWAT SEDERHANA UNTUK SISWA SEKOLAH DASAR
}

\author{
Windha Octafiana ${ }^{1}$, Madyo Ekosusilo ${ }^{2}$, Singgih Subiyantoro ${ }^{3}$ \\ Program Studi Teknologi Pendidikan,Universitas Veteran Bangun Nusantara ${ }^{1,2,3}$ \\ Email : windhactafiana@gmail.com ${ }^{1}$
}

\begin{abstract}
Abstrak
Penelitian ini bertujuan untuk mengembangan multimedia interaktif yang layak dan tepat digunakan pada pembelajaran IPA khususnya Pesawat Sederhana kelas V Sekolah Dasar Negeri III Kudi Batuwarno Wonogiri. Metode penelitian yang digunakan adalah metode Penelitian dan Pengembangan Research and Development ( R \& D ) dengan model pengembangan yang digunakan adalah model ADDIE. Model ini sesuai dengan namanya, terdiri dari lima fase atau tahap utama, yaitu (A)nalysis, (D)esign, (D)evelopment, (I)mplementation, dan (E)valuation. Hasil penelitian dan pengembangan menunjukan bahwa multimedia interaktif pada materi pesawat sederhana untuk siswa kelas V Sekolah Dasar Negeri III Kudi Batuwarno Wonogiri telah selesai dilaksanakan. Pada Tahap ahli, ahli materi memberikan penilaian terhadap produk sebesar 3,37 (kategori Sangat baik). Penilaian oleh ahli media sebesar 3,10 (kategori Baik). Multimedia interaktif pada uji coba perorangan diperoleh skor sebanyak 3,30 (kategori sangat baik), uji coba kelompok kecil sebesar 3,50 (kategori sangat baik) dan hasil pemahaman siswa rata-rata Post Test kelompok kontrol 6,1 dan kelas eksperimen 8,8. Pada uji t dengan tingkat kemaknaan 0,05 yaitu terdapat perbedaan yang signifikan terhadap multimedia yang dikembangkan. Adapun kesimpulan dari penelitian ini adalah produk multimedia interaktif yang dihasilkan sudah layak dan tepat digunakan untuk meningkatkan motivasi dan hasil belajar belajar siswa kelas V Sekolah Dasar Negeri III Kudi Batuwarno Wonogiri.
\end{abstract}

Kata Kunci : Multimedia Interaktif, Pesawat Sederhana, Sekolah Dasar

\section{THE DEVELOPMENT OF INTERACTIVE MULTIMEDIA ON SIMPLE AIRPLANES MATERIAL FOR STUDENT IN ELEMENTARY SCHOOL}

\author{
Windha Octafiana $^{1}$, Madyo Ekosusilo $^{2}$, Singgih Subiyantoro $^{3}$ \\ Program Studi Teknologi Pendidikan,Universitas Veteran Bangun Nusantara ${ }^{1,2,3}$ \\ Email : windhactafiana@gmail.com ${ }^{1}$
}

\begin{abstract}
This study aims to develop appropriate and appropriate interactive multimedia used in science learning, especially Simple Aircraft class V State Elementary School III Kudi Batuwarno Wonogiri. The research method used is the Research and Development Research and Development $(R \& D)$ method with the development model used is the ADDIE model. This model is consistent with its name, consisting of five phases or the main stages, namely (A) nalysis, (D) esign, (D) evelopment, (I) mplementation, and $(E)$ valuation. The results of research and development shows that interactive multimedia on simple aircraft materials for grade V students of State Elementary School III Kudi Batuwarno Wonogiri has been completed. At the Expert Phase, the material expert gives an assessment of the product of 3.37 (Excellent category). Assessment by a media expert of 3.10 (Good category). Interactive multimedia in individual trials obtained a score of 3.30 (excellent category), small group trials of 3.50 (excellent category) and students' average comprehension result of Post Test of control group 6.1 and experimental class 8, 8. In the $t$ test with a significance level of 0.05 ie there is a significant difference to the multimedia developed.The conclusion of this research is interactive multimedia product that is produced is feasible and appropriately used to improve the motivation and learning outcomes of students of grade V State Elementary School III Kudi Batuwarno Wonogiri.
\end{abstract}

Keywords: Interactive Multimedia, Simple Airplanes, elementary school 


\section{PENDAHULUAN}

Perkembangan Ilmu Pengetahuan dan Teknologi (IPTEK) begitu cepat, menyebabkan seorang guru tidak lagi mampu menyampaikan informasi atau menguasai semua fakta dan konsep dari berbagai cabang ilmu, walaupun hal tersebut telah digelutinya selama bertahuntahun. Pemakaian teknologi didasarkan atas berbagai alasan diantaranya efisiensi, keefektifan, dan juga kenyamanan yang telah disebutkan diatas.

Persaingan yang semakin ketat dalam dunia kerja, menuntut adanya peningkatan kompetensi peserta didik. Dalam kondisi semacam ini, pembaruan di bidang pendidikan dan pembelajaran perlu secara terus menerus dilakukan guna meningkatkan kualitas sumber daya manusia (Subiyantoro \& Mulyani, 2017)
Ilmu pengetahuan Alam, yang sering disebut juga dengan istilah pendidikan sains, disingkat IPA. IPA merupakan salah satu mata pelajaran pokok kurikulum pendidikan, termasuk pada jenjang sekolah dasar. Pendidikan Ilmu Pengetahuan Alam (IPA) diharapkan adanya interaktif antar guru dengan siswa, siswa dengan siswa. Pembelajaran yang terjadi selama ini kurang mampu mengembangkan kemampuan berpikir siswa. Pelaksanaan pembelajaran hanya diarahkan pada kemampuan siswa untuk menghafal informasi, otak siswa dipaksa untuk mengingat dan menimbun berbagai informasi tanpa dituntut untuk memahami informasi yang diperoleh untuk menghubungkannya dengan situasi dalam kehidupan sehari-hari (Susanto, 2013: 165).

Tabel 1.1 Hasil Ulangan Tengah Semester Kelas V Tahun Ajaran 2017/2018

\begin{tabular}{clrc}
\hline No. & Mata Pelajaran & KKM & Tingkat Ketercapaian \\
\hline 1 & Bahasa Indonesia & 71 & $60 \%$ \\
2 & IPA & 70 & $40 \%$ \\
3 & Matematika & 60 & $50 \%$ \\
\hline
\end{tabular}

Berdasarkan hasil tabel diatas menunjukkan hasil belajar IPA pada siswa Kelas V SDN III Kudi yang berjumlah 10 siswa cukup rendah. Kriteria Ketuntasan Minimal (KKM) pada mata pelajaran IPA adalah 70. Berdasarkan KKM tersebut, hanya sekitar $40 \%$ siswa yang memenuhi Kriteria Ketuntasan Minimal (KKM).
Sedangkan $60 \%$ siswa masih memiliki nilai IPA dibawah Kriteria Ketuntasan Minimal (KKM). Hal tersebut menunjukan bahwa masih banyak siswa yang mendapat nilai dibawah Kriteria Ketuntasan Minimal (KKM) pada mata pelajaran IPA.

Karakter belajar anak mayoritas lebih memilih ketika belajar sambil bermain. 
Oleh karena itu, di zaman yang serba modern ini, banyak bermunculan permainan pada komputer. Maka dari itu, muncul sebuah gagasan untuk menggunakan multimedia interaktif yang dapat membantu anak dalam mempelajari mata pelajaran IPA. Selain itu untuk memotivasi, menarik minat siswa dalam belajar (Yeni, 2013).

Pembelajaran sebelumnya menggunakan metode yang bersifat klasikal sehingga kurang menarik, kurang efektif dan kurang efisien. Melalui media ini diharapkan ada pembaharuan metode baru sehingga siswa lebih terpacu rasa ingin tahunya untuk mempelajari yang sudah diberikan oleh guru. Selain itu gaya penyampaian yang digunakan guru untuk menyampaikan materi hanya menggunakan metode ceramah yang berpusat pada papan tulis. Bukan hanya itu dalam penyampaian materi guru sekedar menyampaikan materi saja tanpa harus mengetahui apakah siswanya paham dan mengerti dengan materi yang disampaikan.

Sekolah yang berada di pedesaan membuat siswa sangat asing dengan barang elektronik serta tidak adanya sarana prasarana yang memadai untuk siswa dapat menggunakan benda elektronik untuk kegiatan pembelajaran. Walaupun seperti itu di sekolah tersebut memiliki guru-guru muda yang mayoritas sudah paham dengan benda elektronik, internet maupun sejenisnya. Dengan adanya guru muda tersebut sedikit membantu dalam membimbing siswa untuk menggunakan multimedia interaktif yang akan dikembangkan ini. Selain itu dengan jumlah siswa yang relatif sedikit dan dengan jumlah guru muda yang relatif banyak serta paham dengan IPTEK dapat lebih meningkatkan efektifitas dan efisiensi kegiatan pengembangan multimedia interaktif dalam pembelajaran. Siswa lebih bisa berperan aktif, materi yang disampaikan dapat dimengerti siswa dengan mudah, serta siswa dapat mencoba kembali multimedia tersebut di rumah. Hal terpenting adalah siswa memiliki komputer atau laptop. Siswa bisa menyimpan media tersebut pada CD/DVD, flashdisk atau alat penyimpanan elektronik lainnya, kemudian multimedia interaktif tersebut dapat digunakan dikomputer atau laptop masingmasing di rumah siswa. Jadi siswa dapat menggunakan media tersebut baik didalam maupun diluar proses pembelajaran.

\section{METODE PENELITIAN}

Jenis penelitian yang digunakan adalah jenis penelitian dan pengembangan atau dalam bahasa inggrisnya Research and Development (R\&D). R\&D adalah jenis penelitian yang digunakan untuk menghasilkan produk tertentu, dan menguji keefektifan produk tersebut. Untuk dapat menghasilkan produk tertentu digunakan penelitian yang bersifat analisis kebutuhan dan untuk menguji keefektifan produk tersebut supaya dapat berfungsi 
dimasyarakat luas, maka diperlukan penelitian untuk menguji keefektifan produk tersebut (sugiyono, $2014: 407$ ).

Pada penelitian ini, model pengembangan yang digunakan adalah model ADDIE. Model ADDIE merupakan salah satu model desain system pembelajaran yang memperhatikan tahapan-tahapan desain system pembelajaran yang sederhana dan mudah dipelajari. Model ini sesuai dengan namanya, terdiri dari lima fase atau tahap utama, yaitu (A)nalysis, (D)esign, (D)evelopment, (I)mplementation, dan (E)valuation.

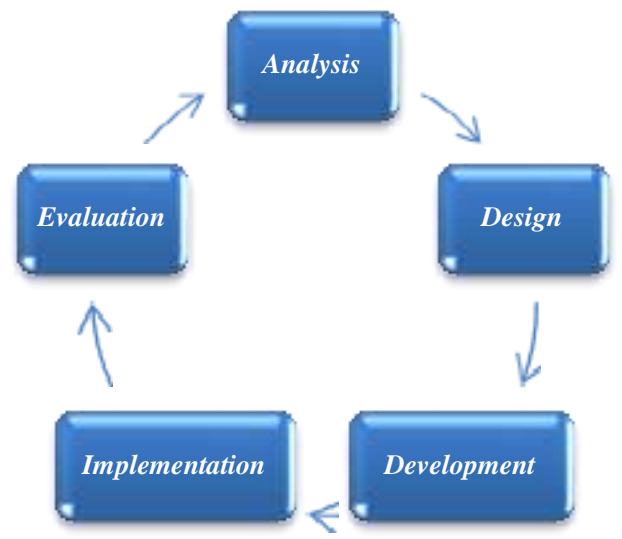

Gambar Prosedur Penelitian Pengembangan Model ADDIE

\section{HASIL DAN PEMBAHASAN}

Penelitian ini menghasilkan suatu produk berupa multimedia interaktif pembelajaran pada mata pelajaran Ilmu Pengetahuan Alam khususnya pada materi Pesawat Sederhana untuk siswa kelas V di Sekolah Dasar Negeri III Kudi Batuwarno Wonogiri. Penelitian ini dilakukan dengan lima tahap diantaranya : Analysis, Design,
Development, Implementation, dan Evaluation.

\section{Tahap Analysis (Analisis)}

Langkah pertama yang dilakukan dalam analisis kebutuhan ini adalah menemukan masalah. Pada tahap ini melihat langsung keadaan sekolah, proses pembelajaran, dan potensi yang dapat dikembangkan sebagai dasar dalam menetapkan masalah yang dihadapi dalam pembelajaran Ilmu Pengetahuan Alam (IPA). Beberapa yang diperlukan dalam analisis ini untuk menyusun multimedia interaktif, diantaranya menggunakan standar kompetensi (SK), Kompetensi Dasar (KD), dan Indikator yang didasarkan pada Standar Kompetensi dan Kompetensi Dasar yang telah disusun oleh TIM Penyusun Kurikulum.Menurut Havighurst dalam Desmita (2014:35).

\section{Tahap Design (Desain)}

Pengembangan multimedia interaktif ini dilakukan desain aplikasi untuk menentukan layout dan fungsi-fungsi yang akan dimuat dalam aplikasi. Pada tahap ini Media dibuat dengan menggunakan beberapa program pendukung yaitu Adobe Flash Profesional CS6 sebagai aplikasi utama. Karena aplikasi Adobe Flash Profesional CS6 dirasa paling cocok digunakan untuk pembuatan media pembelajaran, dengan memanfaatkan ActionScrip 3.0 Aplikasi. 


\section{Tahap Development (Pengembangan)}

Data Validasi Ahli Materi yang dilakukan oleh ahli materi dilihat dari segi isi materi yang disajikan dalam multimedia interaktif serta dari segi pemelajaran. Ahli materi dalam pengembangan multimedia ini adalah Ibu Para Mitta Purbosari, M.Pd dosen Pendidikan Guru Sekolah Dasar Universitas Veteran Bangun Nusantara Sukoharjo. Hasil penilaian ahli materi pada tahap pertama memperoleh jumlah skor 37 dengan rata-rata 3.37. Berdasarkan uji kelayakan, maka produk multimedia yang dikembangkan termasuk dalam kategori baik.

Data Validasi Ahli Media Hasil penilaian dari ahli media pada tahap pertama memperoleh jumlah skor 27 dengan rata-rata 2,70. Berdasarkan tabel uji kelayakan, maka produk multimedia yang dikembangkan termasuk dalam kategori baik. Meskipun demikian, masih terdapat beberapa poin aspek yang masih kurang sehingga perlu dilakukan perbaikan. Saran yang diberikan oleh ahli media adalah sebagai berikut : Tulisan disesuaikan dengan background yang lebih menarik atau lebih konsisten, Animasi dibenahi, Quiz sudah bagus, ada 1 nomer yang harus dibenahi, Pemilihan Tulisan disesuaikan dengan Background yang lebih menarik, animasi diberi efek bergerak dan diberi kata-kata saat pointer didekatkan.

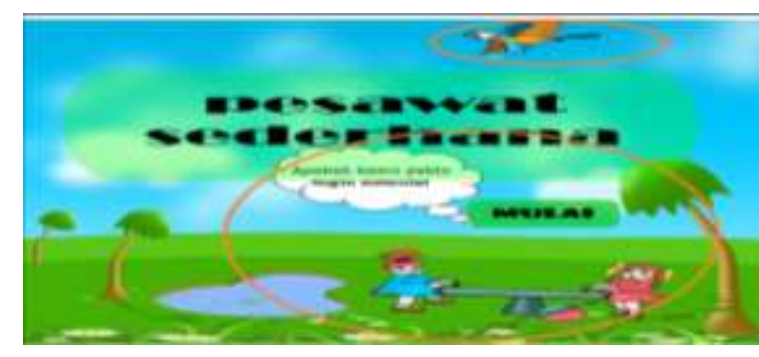

Gambar Tampilan Opening

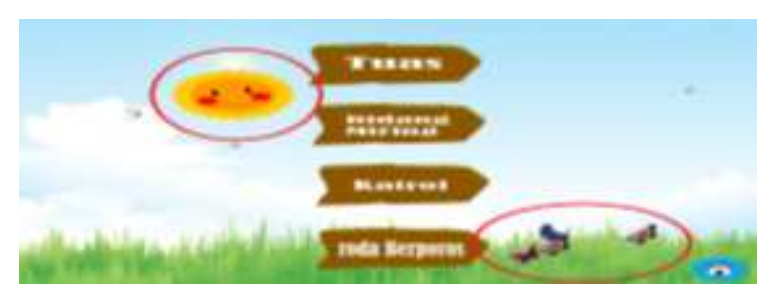

Gambar 4.12 Tampilan Materi

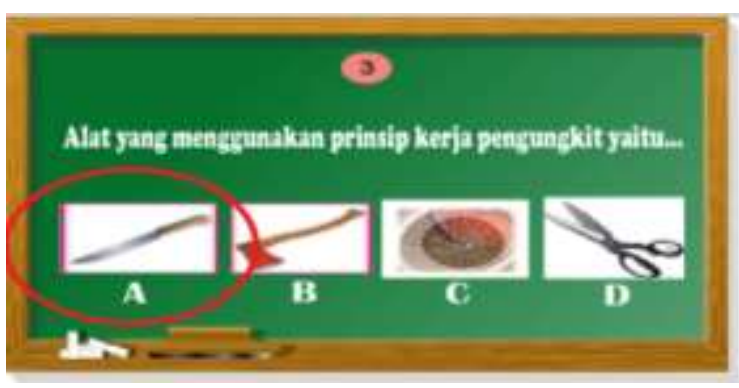

Gambar Tampilan Quiz

\section{Tahap Implementation (Implementasi)}

Uji coba perorangan berjumlah 3 orang siswa kelas V. Responden diminta untuk menggunakan multimedia interaktif kemudian diberi lembar evaluasi untuk memberikan penilaian terhadap multimedia interaktif yang telah digunakan. Adapun hasil uji coba perorangan adalah sebagai berikut : 
Tabel Data Hasil Uji Coba Perorangan

\begin{tabular}{|c|c|c|c|}
\hline No & Pertanyaan & $\begin{array}{l}\text { Jumlah } \\
\text { Skor }\end{array}$ & Rata-rata \\
\hline 1. & $\begin{array}{l}\text { Setiap kalimat yang dituliskan dalam } \\
\text { multimedia mudah dipahami }\end{array}$ & 12 & 4,00 \\
\hline 2. & Materi yang disajikan mudah dipahami & 11 & 3,67 \\
\hline 3. & Multimedia membantu dalam belajar & 10 & 3,33 \\
\hline 4. & $\begin{array}{l}\text { Saya dapat belajar sendiri tanpa bantuan } \\
\text { orang lain }\end{array}$ & 7 & 2,33 \\
\hline 5. & Letak tombol dan tulisan sudah sesuai & 9 & 3,00 \\
\hline 6. & Petunjuk yang disajikan sudah cukup jelas & 10 & 3,33 \\
\hline 7. & $\begin{array}{l}\text { Gambar yang digunakan sebagai } \\
\text { background/ latar belakang menarik }\end{array}$ & 11 & 3,67 \\
\hline 8. & Tulisan dapat dibaca dengan mudah dan jelas & 9 & 3,00 \\
\hline 9. & Gambar/animasi menarik & 11 & 3,67 \\
\hline 10. & Tombol yang disajikan jelas & 9 & 3,00 \\
\hline & $\begin{array}{c}\text { Jumlah } \\
\text { Rata-rata } \\
\text { Kriteria }\end{array}$ & & $\begin{array}{c}33 \\
\text { 3,30 } \\
\text { Sangat Baik }\end{array}$ \\
\hline
\end{tabular}

Jumlah skor yang diperoleh pada uji coba perorangan yaitu 33 sehingga bila dihitung rata-rata mencapai 3,30. Berdasarkan tabel uji kelayakan, maka produk multimedia termasuk kategori "sangat baik". Uji coba kelompok kecil dilakukan pada responden yang berjumlah 8 orang siswa kelas V. Responden diminta untuk menggunakan multimedia interaktif kemudia diberi lembar evaluasi untuk menilai multimedia yang telah digunakan. Jumlah skor yang diperoleh pada uji coba kelompok kecil yaitu 35 sehingga bila dihitung rata-rata mencapai 3,50. Berdasarkan tabel uji kelayakan, maka produk multimedia termasuk kategori "sangat baik".

\section{Tahap Evaluation (Evaluasi)}

Uji lapangan dilakukan pada tanggal 11 Mei 2018. Responden dalam uji lapangan ini seluruh kelas V SD yang berjumlah 10 orang siswa. Tahap ini siswa diberi Pre test dan post test untuk mengetahui tingkat pemahaman siswa terhadap pesawat sederhana. Penyajian data pre test dan post test yang didapat dari uji lapangan disajikan dalam tabel berikut :

Tabel Hasil Post Test Kelas Eksperimen dan Kelas Kontrol

\begin{tabular}{ccc}
\hline No & Eksperimen & Kontrol \\
\hline 1. & 100 & 50 \\
2. & 90 & 70 \\
3. & 100 & 80 \\
4. & 100 & 70 \\
5. & 50 & 50 \\
6. & 80 & 40 \\
7. & 80 & 80 \\
8. & 90 & 60 \\
9. & 100 & 50 \\
10. & 90 & 60 \\
\hline Rerata & 8,8 & 6,1 \\
\hline
\end{tabular}

Nilai t hitung adalah 4.128 dengan sig 0,001. Karena sig $<0,005$ maka dapat 
disimpulkan bahwa $\mathrm{H}_{\mathrm{o}}$ ditolak dan $\mathrm{H}_{\mathrm{a}}$ diterima terdapat perbedaan hasil belajar yang signifikan antara siswa yang menggunakan multimedia (kelas eksperimen) dan siswa yang tanpa menggunakan multimedia (kelas kontrol) pada mata pelajaran ilmu pengetahuan alam khususnya pesawat sederhana.

Selain untuk meningkatkan hasil belajar siswa pengembangan multimedia interaktif ini juga untuk memotivasi belajar siswa. Pelaksanaan uji lapangan yang dilakukan untuk mengumpulkan data awal sebelum menggunakan multimedia dan data akhir setelah menggunakan multimedia. Selain itu juga untuk membandingkan antara kelas eksperimen yang menggunakan multimedia yang berjumlah 10 siswa dan kelas kontrol yang tidak menggunakan multimedia yang berjumlah 10 siswa.

Tabel Data Tingkat Motivasi Belajar Kelas Eksperimen dan Kelas Kontrol

\begin{tabular}{clllllll}
\hline No & \multirow{2}{*}{ Indikator } & \multicolumn{3}{c}{ Kelas Eksperimen } & \multicolumn{3}{c}{ Kelas Kontrol } \\
\cline { 2 - 7 } & Pretest & Posttest & Selisih & Pretest & Posttest & Selisih \\
\hline 1 & Minat & 65 & 85 & 20 & 60 & 70 & 10 \\
2 & $\begin{array}{l}\text { Hasrat untuk } \\
\text { belajar }\end{array}$ & 60 & 80 & 20 & 60 & 70 & 10 \\
3 & $\begin{array}{l}\text { Dorongan dan } \\
\text { kebutuhan belajar }\end{array}$ & 68 & 80 & 12 & 62 & 65 & 3 \\
4 & $\begin{array}{l}\text { Kegiatan belajar } \\
\text { menarik }\end{array}$ & 68 & 95 & 27 & 50 & 65 & 15 \\
\hline & Rerata & $\mathbf{6 5 , 2}$ & $\mathbf{8 5 , 0}$ & $\mathbf{1 9 , 7}$ & $\mathbf{5 8 , 0}$ & $\mathbf{6 7 , 5}$ & $\mathbf{9 , 5}$ \\
\hline
\end{tabular}

Berdasarkan data tingkat motivasi belajar diatas dapat disimpulkan bahwa ada perbedaan hasil belajar dan motivasi belajar yang signifikan antara kelas eksperimen yang menggunakan multimedia yang berjumlah 10 siswa dan kelas kontrol yang tidak menggunakan multimedia yang berjumlah 10 siswa.

\section{KESIMPULAN DAN SARAN}

Multimedia Interaktif dikatakan layak dan tepat digunakan dalam pembelajaran apabila telah memenuhi syarat-syarat penilaian dari aspek pembelajaran, aspek materi, aspek bahasa, aspek layout, aspek motivasi dan aspek manfaat yang telat dinilai oleh ahli materi, ahli media, dan pengguna. Hasil dari penelitian Pre Test dan Post Test kelas eksperimen 6,1 dan 8,8 sedangkan kelas kontrol 6,0 dan 6,1. Hal ini ditunjukan bahwa ada perbedaan hasil belajar dan motivasi belajar yang signifikan antara kelas eksperimen yang menggunakan multimedia yang berjumlah 10 siswa dan kelas kontrol yang tidak menggunakan multimedia yang berjumlah 10 siswa. 
Selain menggunakan multimedia interaktif diharapkan siswa juga mencari sumber lain untuk menambah wawasan materi IPA khususnya pesawat sederhana. Serta guru diharapkan dapat membuat media pembelajaran yang inovatif dan sederhana yang bisa membuat siswa tertarik dan mempermudah siswa untuk memahami mata pelajaran.

\section{DAFTAR PUSTAKA}

Desmita. 2014. Psikologi Perkembangan Peserta Didik (Panduan bagi Orangtua dan Guru dalam Memahami Psikologi Anak Usia SD, SMP dan SMA). Bandung: PT Remaja Rosdakarya.

Krismawati Yeni. 2013. Teori Perkembangan Erik H. Erikson dan Manfaatnya Bagi Tugas Pendidikan Kristen Dewasa Ini. Jurnal Teknologi dan Pendidikan Agama Kristen. Vol.2, No.1.

Pandantoyo Huda. Pengaruh Media Pembelajaran Berbasis Multimedia Terhadap Motivasi dan Hasil Belajar Materi sistem Pencernaan Manusia. Jurnal Dinamika Penelitian. Vol.16, No.1.

Permana Erwin \& Nourmavita Desy. Pengembangan Multimedia Interaktif Pada Mata Pelajaran IPA Materi Mendeskripsikan Daur Hidup Hewan Di Lingkungan Sekitar Siswa Kelas IV Sekolah Dasar. Jurnal Ilmiah Pendidikan Guru Sekolah Dasar. Vol. 10, No.2.

Rohmat. 2009. Terapan Teori Teknologi Instruksional. Yogyakarta: Logung Pustaka

Sri riani. 2013. Pengembangan Media Pembelajaran Berbasis Multimedia Interaktif Untuk Meningkatkan Pemahaman Materi Bioteknologi
Moderen. Jurnal Pendidikan Biologi Indonesia. Vol.1, No.1.

Subiyantoro, S., \& Ismail. (2017). DAMPAK LEARNING MANAGEMENT SYSTEM (LMS) PADA PERFORMA AKADEMIK MAHASISWA DI PERGURUAN TINGGI. Edudikara: Jurnal Pendidikan dan Pembelajaran, Vol 2 (4)

Subiyantoro, S., \& Mulyani, S. (2017).

KEGUNAAN MULTIMEDIA

INTERAKTIF DALAM

PEMBELAJARAN BAHASA

INGGRIS. Edudikara: Jurnal

Pendidikan Dan Pembelajaran, 2(2), 92-100.

Sugihartono. 2013. Psikologi Pendidikan. Yogyakarta: UNY Press.

Sugiyono. 2014. Metode Penelitian Pendidikan (Pendekatan Kuantitatif, Kualitatif, dan $R$ \& D). Bandung: Alfabeta.

Sutikno, M Sobry. 2014. Metode \& ModelModel Pembelajaran. Lombok: Holistica.

Susanto, Ahmad. 2013. Teori Belajar \& Pembelajaran di Sekolah Dasar. Jakarta: Prenadamedia Group.

Winarno (2009). Teknik Evaluasi Multimedia Pembelajaran, Jakarta: Genius Prima Media 